Economia e Sociedade, Campinas, Unicamp. IE.

http://dx.doi.org/10.1590/1982-3533.2015v24n1 art5

\title{
Interação Universidade-Empresa: o caso do setor sucroalcooleiro de Pernambuco *
}

\author{
Fagner Diego Spíndola ** \\ João Policarpo Rodrigues Lima ${ }^{* * *}$ \\ Ana Cristina Fernandes ${ }^{* * * *}$
}

\begin{abstract}
Resumo
O trabalho apresenta um panorama atual da inovação no setor sucroalcooleiro pernambucano, cujo objetivo foi melhor entender as interações das empresas com as universidades e institutos públicos de pesquisa que têm promovido alguma inovação no setor. Adicionalmente, testou-se a hipótese, através do estudo de caso, de que o segmento supracitado preservou traços de sua história que legaram uma postura de setor pouco inovativo e dependente de proteção governamental. Parte de pesquisa mais ampla, o presente trabalho resulta de estudo de caso em que foram entrevistados agentes envolvidos com a interação U-E em usinas de açúcar, na instituição patronal e em instituições de pesquisa em Pernambuco. O estudo permitiu verificar que a inovação nesse setor ocorre de forma distinta em cada um dos três diferentes segmentos em que está subdividido: agricultura, indústria e transporte e mecanização. Na área agrícola, as empresas introduzem inovações que, no entanto, são desenvolvidas por instituições públicas de pesquisa existentes no estado, como a Ridesa e o Cetene, para quem as usinas e os pequenos produtores transferem esforços em $\mathrm{P} \& \mathrm{D}$. Na área industrial e na de transporte $\mathrm{e}$ mecanização, as inovações são introduzidas por intermédio do sindicato patronal e de empresas de consultoria técnica que as importam de outras regiões ou países, enquanto o desenvolvimento de novos produtos não foi observado na indústria sucroalcooleira pernambucana. O foco das usinas locais é o mercado externo de açúcar por possuírem uma vantagem comparativa logística e contarem internamente com grande concorrência de produtores do Centro-Sul. Essa exportação do açúcar tem sido feita a granel, levando a crer que os produtores têm passado adiante parte importante da agregação de valor ao produto, deixando os procedimentos mais específicos, como criação de produtos finais diferenciados, para o importador e, por isso, perdendo oportunidades de inovar em produtos. A oferta de mão de obra, historicamente abundante, parece tender a uma escassez futura, levando as usinas a se movimentarem mais recentemente em direção à mecanização da colheita da cana. $\mathrm{O}$ capital externo parece desinteressado no setor, tendo em vista a menor automação da colheita da cana no estado; por conseguinte, a dinâmica tecnológica não sofre mudanças mais significativas que poderiam advir da chegada de empresas multinacionais, em princípio mais afeitas a investimentos em $\mathrm{P} \& \mathrm{D}$ e à interação mais intensa com instituições de pesquisa.
\end{abstract}

Palavras-chave: Inovação; Nordeste/Pernambuco; Açúcar e álcool.

* Trabalho recebido em 12 de dezembro de 2012 e aprovado em 8 de setembro de 2014. Os autores expressam seu agradecimento aos comentários e sugestões feitos pelos avaliadores a uma versão anterior do artigo.

${ }^{* *}$ Doutorando em Economia, PIMES/UFPE (Universidade Federal de Pernambuco. Programa de PósGraduação em Economia), Recife, PE, Brasil. E-mail: fdspindola@gmail.com.

${ }^{* * *}$ Professor do Departamento de Economia, PIMES/UFPE / Pesquisador do CNPq (Conselho Nacional de Desenvolvimento Científico e Tecnológico), Recife, PE, Brasil. E-mail: jprlima@ufpe.br.

**** Professora do Departamento de Geografia da UFPE e pesquisadora do CNPq, Recife, PE, Brasil. E-mail: anacf.ufpe@gmail.com. 


\begin{abstract}
University-Enterprise Interaction: the case of Pernambuco's sugar-alcohol sector

This work presents an overview of the sugarcane sector, whose objective was to better understand the interactions of firms with universities and/or technical consulting organizations that have promoted some innovation in the sector. Additionally, it was tested the hypothesis, through the case study, that the segment above preserved traces of its history that left the impression of a sector less innovative and dependent on government protection. The paper, based on a case study, has shown that companies have a R\&D continuum in the agricultural area, although sugar mills and small producers relegate efforts in $\mathrm{R} \& \mathrm{D}$, transferring this role to institutions such as RIDESA and CETENE. The focus of local mills is on the foreign market of sugar since they have a comparative advantage in logistics and also a big competition from other Brazilian producers. The exports of sugar have been made in bulk, implying that producers have passed on an important part of adding value to the product, leaving the procedures related to the importers and, by consequence, losing opportunities to innovate with differentiated products. The supply of labor seems likely to lead to future scarcity, causing the mills to move toward mechanization of part of the production. The foreign capital seems uninterested in the sector, considering a smaller automation of cane harvesting in the state, hence the technological dynamics does not suffer major changes that could result from the arrival of these companies, in principle, more keen on investments in R\&D and stronger interaction with research institutions.
\end{abstract}

Key-words: Innovation; Northeast/Pernambuco; Sugar and alcohol.

JEL O31.

\title{
Introdução
}

A formação de um sistema nacional de inovação (SNI) é reconhecida como preponderante para o processo de desenvolvimento das nações, sejam elas especializadas em setores mais ou menos intensivos em tecnologia e que enfrentem concorrência interna ou externa (Freeman, 1995; Nelson, 1993; Lundvall, 1992). Segundo Nir (1987), a abordagem sistêmica é estruturada para lidar com problemas grandes e complexos, dado que um fenômeno nunca é isolado e se inter-relaciona com fatores de fenômenos distintos que se tangenciam. Esse enfoque defende que a formação de um SNI deve ser de preocupação do Estado, não só das empresas, com o intuito de proporcionar condições adequadas para o desenvolvimento sustentável de suas economias, dado que alguns tipos de investimentos que exigem longo prazo de maturação podem ser custeados apenas por governos ${ }^{1}$, particularmente na escala nacional (Landes, 1970 apud Freeman, 1995).

Segundo Freeman (1995), a história da construção do SNI em diversos países ao redor do mundo explica os diferentes estágios de desenvolvimento observados entre eles. Isso porque, historicamente, suas sociedades têm organizado e sustentado o desenvolvimento de diferentes formas, no que são afetadas pela introdução, melhoria e difusão de novos produtos e processos em suas economias

(1) O setor sucroalcooleiro, conforme será mais bem explicitado adiante, historicamente se enquadra nessa situação, especificamente pelo perfil do empresariado do setor. 
nacionais. Nessa perspectiva histórica, Suzigan e Albuquerque (2008) argumentam que a formação do SNI no Brasil foi acompanhada por um latente atraso que se desenvolveu desde o período colonial brasileiro. $\mathrm{O}$ começo tardio da industrialização, da construção das instituições de pesquisa e ensino superior e do sistema financeiro constitui importante componente para a compreensão dos atuais limites do SNI brasileiro. Nesse contexto tardio, interações entre universidades e institutos de pesquisa e empresas em busca de inovações ocorrem de forma esporádica e concentradas em alguns poucos pontos entre áreas de conhecimento e setores de atividade econômica.

No caso do Nordeste, a exemplo de outras economias regionais consideradas retardatárias, em oposição ao observado em regiões dinâmicas, observa-se um número menor ainda de pontos de interação com capacidade de autopropulsão, os quais frequentemente contam com o estímulo do Estado para se desencadear, como observa Fernandes et al. (2011, p. 1-2):

[...] em regiões compreendidas como periféricas ao sistema já tardio brasileiro, como é o caso do Nordeste, as interações são ainda mais raras: a criação de instituições científicas e tecnológicas é ainda mais recente, o sistema financeiro regional virtualmente deixou de existir e, perante uma estrutura produtiva baseada em setores tradicionais, apenas recentemente expostos à concorrência externa, a motivação para as interações mostra-se ainda mais limitada [...]. (Esta) decorreria mais da estrutura de incentivos disponibilizada pelo Estado tanto às firmas quanto à academia, do que das demais variáveis que determinam o estabelecimento de relações entre universidades e indústrias.

Como parte importante desse contexto, destaca-se a indústria sucroalcooleira no Nordeste, em geral, e em Pernambuco, em particular, a qual apresenta uma formação peculiar, já exposta por Rogers (2008). Para esse autor, a formação de poderes econômicos e políticos no setor limitava a abertura ao novo, visto que qualquer mudança nas rotinas representava uma ameaça implícita à alteração no status quo de sua fração de classe social. A literatura de história econômica da região (Eisenberg, 1974; Lima, 1988; Rogers, 2008) permite verificar que se trata de uma indústria pouco inovativa por razões histórico-culturais que levaram os empresários a recorrer mais intensa e frequentemente a subsídios fiscais e a outros benefícios governamentais, de um lado, e à mão de obra barata e abundante, de outro, do que à introdução de novos, ou melhoria de, produtos e processos.

Debruçando-se sobre esse contexto, o presente trabalho está inserido num projeto de pesquisa mais amplo acerca da inter-relação entre universidades e institutos de pesquisa e empresas no Nordeste brasileiro que pretende avaliar as características e o contexto institucional do padrão de interação observado em regiões com sistema de inovação imaturo e periférico, como os existentes no 
Nordeste do Brasil ${ }^{2}$. Com apoio na literatura e na base de dados construída para a pesquisa mais ampla, a partir do Diretório dos Grupos de Pesquisa do CNPq, podese formular a hipótese de que, se de um lado, os pontos de interação ocorrem mais frequente e exitosamente nos casos em que a base científica e tecnológica é mais antiga e mais solicitada pela atividade econômica, como proposto por Suzigan e Albuquerque (2008), por outro lado, a baixa capacidade de demanda por inovação por parte dos setores econômicos somada a uma base científica e tecnológica relativamente recente, que ainda prevalecem na Região Nordeste, levam a um diálogo limitado entre empresas e universidades e institutos de pesquisa. A matriz de pontos de interação identificados em etapas anteriores do trabalho focado no Nordeste (Fernandes et al., 2011) fundamenta essa hipótese.

Como fonte de informação complementar à base de dados mencionada e estratégia de investigação com vistas a aprofundar o debate em torno da hipótese acima citada, a pesquisa previu a realização de estudos de caso, que constituem um dos seus módulos. Nesse sentido, foram selecionados os pontos de interação mais intensos (maior número de relacionamentos), que foram, em seguida, classificados por motivação da relação (iniciativa da empresa ou do pesquisador) e por orientação de mercado (regional, nacional, global).

O presente artigo trata de um desses estudos de caso, cuja metodologia será exposta adiante, de pontos de interação: o setor sucroalcooleiro e a área de conhecimento de agronomia no estado de Pernambuco. Compreendido como um setor importante economicamente no estado e de grande relevância histórica para a economia nordestina, o sucroalcooleiro pernambucano é conhecido por seu foco no mercado externo de açúcar, o que o expõe a um ambiente de elevada competitividade, e pela antiga relação com instituições regionais de pesquisa.

A realização deste estudo de caso constitui interessante oportunidade para testar a hipótese mencionada, diante do fato de que a base científica e tecnológica competente para atender as demandas do setor é das mais antigas disponíveis no estado e, no entanto, a sucroalcooleira pernambucana é reconhecida como uma indústria pouco inovativa. Ademais, a introdução ou melhoria de produtos e processos, quando ocorre, parece resultar mais de estímulos ou de suporte governamental do que de iniciativas motivadas pela indústria.

Nesse sentido, além da pesquisa na literatura para a reconstituição histórica da inovação no setor, foram realizadas entrevistas com representantes empresariais

(2) Projeto "Interação entre Universidades/Instituições de Pesquisa e Empresas no Nordeste Brasileiro: Contribuições da Geografia da Inovação”, Edital CNPq/Universal 14/2008, sob a coordenação da Profa . Ana Cristina Fernandes. Este, por sua vez, está inserido no projeto "Interações de Universidades/Instituições de Pesquisa com Empresas Industriais no Brasil”, Edital Fapesp Projeto Temático 2006, coordenado pelo Prof. Wilson Suzigan. Os autores agradecem o auxílio financeiro dessas agências de fomento, assim como aos representantes da indústria sucroalcooleira pernambucana e das instituições de pesquisa entrevistados durante o estudo de caso. 
e patronais e representantes do setor sucroalcooleiro que interagem com universidades e institutos de pesquisa e com pesquisadores líderes de grupos de pesquisa sediados nestes últimos.

O artigo contém uma seção de discussão sobre o referencial teórico, seguido de outra em que é abordada a inovação no segmento sucroalcooleiro no território nordestino numa perspectiva histórica e sua pequena interação com a academia. $\mathrm{Na}$ seção seguinte, é descrita a metodologia do estudo de caso e as entrevistas realizadas junto aos responsáveis pela interação por parte das empresas/usinas consultadas, líderes dos grupos de pesquisa e líderes de entidades de classe e representantes das interações observadas no setor a partir de roteiros definidos pela coordenação da pesquisa. Na última seção, são apresentados os principais resultados do estudo de caso e, nas considerações finais, tecidas as conclusões obtidas.

\section{A inovação tecnológica e o setor sucroalcooleiro}

A inovação tecnológica está no cerne da mudança econômica. Para Rosemberg (1974), o conhecimento científico é demandado quando é estabelecida uma necessidade por esse conhecimento; assim, a origem e o desenvolvimento das ciências têm sido estimulados, ao longo do tempo, pela produção econômica. Para isso, ele elenca possíveis fatores determinantes:

1) Science depends upon industry for financial support. 2) The expectation of high financial returns is what motivates individuals (and society) to pursue a particular scientific problem. 3) The needs of industry serve as a powerful agent in calling attention to certain problems (Pasteur's studies of fermentation and silkworm epidemics). 4) The normal pursuit of productive activities throws up physical evidence of great importance to certain disciplines (metallurgy and chemistry, canal building and geology). As a result, industrial activities have, as a byproduct of their operation, provided the flow of raw observations upon which sciences have built and generalized.

5) The history of individual sciences, including an account of their carrying rates of progress at different periods in history, can be adequately provided by an understanding of the changing economic needs of society (Rosemberg, 1974, p. 7).

Em meio à literatura sobre o tema, sobressai-se o Manual de Oslo (OCDE, 2004). Através dele, pode-se observar as características que tornam as empresas mais, ou menos, inovadoras e como a inovação é gerada no seio das empresas. Assim, conforme o Manual:

[...] a propensão de uma empresa para inovar depende das oportunidades tecnológicas que ela tenha pela frente. Além disso, as empresas diferem em sua capacidade de reconhecer e explorar as oportunidades tecnológicas. Para inovar, uma empresa precisa descobrir quais são essas oportunidades, 
estabelecer uma estratégia apropriada, e ter a capacidade de transformar esses insumos em inovação real - e fazê-lo mais rápido do que seus concorrentes. Mas parar aqui induziria em erro. Diversas oportunidades tecnológicas não surgem por si sós. Antes, são imaginadas pelas empresas para atender algum objetivo estratégico (como satisfazer uma demanda identificada no mercado, por exemplo). A capacidade de inovação consiste em um conjunto de fatores que a empresa tem ou não tem, e nos modos de combiná-los de maneira eficiente. (OCDE, 2004, p. 41).

Seguindo esse raciocínio, o processo de inovação de uma empresa pode ser representado pelo diagrama abaixo, adaptado do modelo de indicadores de inovação publicado no Manual (Figura 1).

Figura 1

Processo de Inovação Empresarial

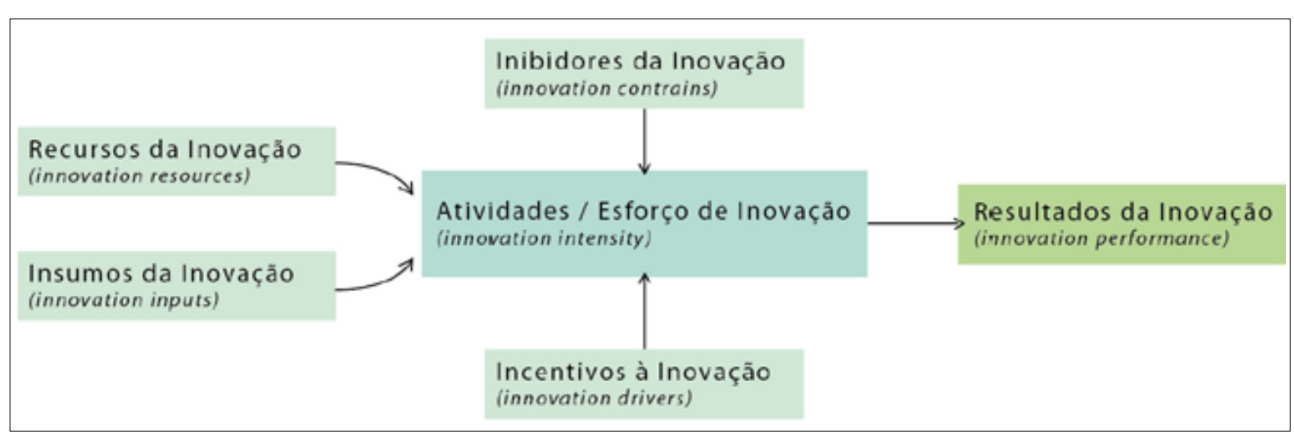

Fonte: Sebrae (2011)

Baseando-se no Manual de Oslo (OCDE, 2004), o processo mostrado na Figura 1 detalha-se da seguinte maneira:

Os recursos de inovação abrangem:

Atividade de P\&D e Design contínuo ou ocasional; equipe de P\&D e Design (número de doutores, mestres e técnicos); instalações de P\&D e Design; orçamento de P\&D e Design.

\section{Os insumos da inovação abrangem:}

Fontes de financiamento; fontes de informação; P\&D interno e demais áreas da empresa; outras empresas do grupo; fornecedores, clientes e concorrentes; universidades, consultores, centros de capacitação e assistência técnica, instituições certificadoras; licenciamento de know-how; conferências, feiras; redes e bases de dados; agentes de cooperação.

Os inibidores da inovação são fatores que dificultam o desenvolvimento das atividades de inovação, tais como: 
Gestores com atitude e cultura conservadoras, fechadas, inflexíveis (que têm aversão a riscos, erros e incertezas), atuação em um mercado conservador, recessivo ou protegido (que não exige); existência de concorrência conservadora ou fraca (que não ameaça); custos e riscos econômicos inerentes à inovação; escassez de financiamento próprio ou externo; falta de pessoal qualificado ou de agentes de cooperação; falta de informação tecnológica ou de mercado; falta de serviços técnicos externos.

Os incentivos à inovação são fatores que alavancam o desenvolvimento das atividades de inovação, tais como:

Gestores com atitude e cultura visionárias, receptivas, flexíveis (que têm tolerância a riscos, erros e incertezas); capacidade de detectar novas oportunidades de mercado inexploradas; atuação em um mercado inovador ou novo (que demanda novidades); existência de ameaças de mercado; existência de concorrência inovadora e destemida; existência de entrantes (novos concorrentes) e substitutos; capacidade de detectar oportunidades tecnológicas; existência de incentivos governamentais à inovação ou ao setor.

Os resultados ou desempenho da inovação são medidas que refletem as consequências das atividades inovadoras:

Ganhos decorrentes de inovações em produto: variação no tempo de vida de produto; variação no tempo decorrido entre desenvolvimento e lançamento de produto no mercado (time-to-market); variação na fatia de mercado (market-share); variação na abertura de novos mercados; variação na gama de produtos ofertados; número de melhorias em produtos existentes; número de novos produtos originais no contexto local; número de novos produtos originais no contexto global; número de patentes de produtos; ganhos decorrentes de inovações em processo; variação no tempo de vida de processo; variação na capacidade dos processos; variação na flexibilidade dos processos; número de melhorias em processos existentes; número de novos processos originais no contexto local; número de novos processos originais no contexto global; número de patentes de processos; variação nos custos de trabalho, energia e matéria-prima; variação nos impactos ambientais; aderência a padrões locais e mundiais.

Neste trabalho, ênfase é dada aos inibidores e incentivos à inovação que cercam a interação universidade-empresa.

Com as considerações acima em mente, será examinado mais de perto, a seguir, o segmento sucroalcooleiro em Pernambuco, que, por bastante tempo, 
recebeu proteção governamental por meio de subsídios fiscais, cotas de exportação ${ }^{3}$, subsídio ao crédito e apoio tecnológico no melhoramento genético.

Para Rossetto (2011), da Agência Paulista de Tecnologia dos Agronegócios, APTA, o desenvolvimento de pesquisas no setor sucroalcooleiro é fundamental para que o Brasil mantenha uma posição de destaque no mercado mundial de biocombustíveis. Segundo a autora, são três as principais áreas de pesquisa no setor:

- Produção agrícola, que envolve trabalhos cujo objetivo é o aumento da produtividade da cana-de-açúcar, como o melhoramento genético, manejo, tratos culturais e desenvolvimento de máquinas e implementos melhor adaptados para a atividade canavieira, sobretudo para a colheita mecânica;

- Produção industrial, que tem como objetivos principais a melhoria da gestão empresarial das usinas e a eficiência da produção de açúcar e etanol, utilizando equipamentos mais eficazes nos processos de fabricação. Atualmente, a pesquisa no setor industrial tem ganho destaque principalmente na produção de etanol a partir dos resíduos da usina, como bagaço ou qualquer outro resíduo vegetal pelo processo de hidrólise enzimática ${ }^{4}$, obtendo-se, assim, um melhor aproveitamento da matéria-prima utilizada;

- Desenvolvimento de novos produtos, além da produção de açúcar e álcool. O setor sucroalcooleiro pode produzir matéria-prima para outras indústrias, como a alcoolquímica, de energia, a alimentícia e mesmo para produção de novos materiais.

A introdução de maquinário, como colheitadeiras e caminhões que transportam a cana colhida, tem contribuído para a redução dos custos de produção das lavouras brasileiras. A mecanização, além de reduzir custos, possibilita a ininterrupção da moagem da cana e proporciona à empresa maior autonomia em relação à mão de obra braçal. Segundo Veiga Filho e Santos (1995 apud Ramão et al., 2007), a mecanização do corte da cana-de-açúcar evidencia uma intensificação do processo de inovação da atividade canavieira e tem sido desenvolvida para atender as demandas por parte dos produtores.

Outro fator que poderá elevar consideravelmente a produtividade das lavouras de cana-de-açúcar é a chamada agricultura de precisão. Trata-se da aplicação de técnicas capazes de identificar/diagnosticar os fatores que podem levar

(3) As cotas de exportação para o mercado dos Estados Unidos ainda existem; no entanto, o percentual das exportações atendido pelas cotas americanas não chega a $2 \%$ da produção total exportada pelos principais estados produtores e exportadores do Norte/Nordeste, Alagoas e Pernambuco (Sindaçúcar - AL, 2014; Brasil, 2010).

(4) Salienta-se que a hidrólise enzimática é apenas uma das rotas tecnológicas pesquisadas para o aproveitamento de resíduos (especificamente os materiais lignocelulósicos) para a produção de etanol, entre as quais estão: hidrólise enzimática, hidrólise e fermentação simultâneas, fermentação etc. Segundo o Prof. Marcos Morais (UFPE), um dos entrevistados neste trabalho, é possível produzir etanol de qualquer substrato que tenha açúcar, observando-se apenas a viabilidade econômica. 
a baixas produtividades e onde elas se manifestam e que, uma vez diagnosticadas, permitem a aplicação/correção dos insumos na dose certa, em cada local. Segundo Molin (2004, p. 2):

A proposta da agricultura de precisão é permitir que se faça em áreas extensas o que os pequenos agricultores sempre fizeram, que é o tratamento dos detalhes considerando as diferenças existentes em um talhão, sem desperdiçar o conhecimento acumulado pelas ciências agrárias até hoje. A ideia básica é de que o agricultor possa inicialmente identificar as manchas de altas e de baixas produtividades dos talhões e depois possa administrar essas diferenças. Para que isso seja possível é necessário certo grau de automatização, que depende de tecnologias modernas, muitas delas apenas adaptadas para o meio agrícola. É o caso do Sistema de Posicionamento Global (GPS), da informática e muitos dos sensores e controladores utilizados nas máquinas.

A agricultura de precisão reúne tecnologias de medição de produtividade, determinação das condições do solo e da planta, estudo da topografia, entre outras informações, associando-as a uma localização específica no campo. Uma vez georreferenciadas, essas informações podem ser expressas na forma de mapas digitais. As informações contidas nesses mapas podem ser processadas para se determinar, por exemplo, a quantidade de insumos que deve ser empregada num determinado local para uma determinada cultura, economizando-se onde o insumo não é necessário e, dessa maneira, otimizando-se os insumos aplicados à cultura. Entender e modelar a variabilidade espacial da produtividade das culturas, das propriedades do solo, planta e de qualquer outro parâmetro que possa estar correlacionado com a produtividade é uma das etapas mais importantes para se estabelecer um processo de gerenciamento localizado de insumos (Oliveira et al., 2002). Adicionalmente, esse procedimento exige a contratação de mão de obra especializada para conduzir o gerenciamento de informações com alto nível de detalhamento. No entanto, salienta-se que a tecnologia relacionada à agricultura de precisão para as plantações de cana ainda está em desenvolvimento, e espera-se que, num futuro próximo, os custos relacionados ao processo se reduzam, levando a uma adoção generalizada por parte das usinas.

Existem ainda outros fatores que podem impulsionar a produtividade da cana-de-açúcar, como a transgenia e o melhoramento genético. Sendo a transgenia assunto bastante polêmico e ainda indefinido pela sociedade brasileira, este artigo apenas discorrerá sobre o melhoramento genético. O uso do melhoramento genético na cultura da cana-de-açúcar trata basicamente do desenvolvimento de variedades mais produtivas e com maior tolerância ao estresse hídrico, maior resistência às pragas e doenças e melhor adaptação à colheita mecanizada. Os órgãos de pesquisa que desenvolvem programas de melhoramento genético da cana utilizam, geralmente, conhecimentos das áreas de biotecnologia, ciências do solo, nutrição de 
plantas, climatologia, fisiologia, fitopatologia, entomologia, economia e outras (Rossetto, 2011).

A exemplo de algumas espécies, as características da cana-de-açúcar são herdadas de forma aditiva. Por exemplo, o cruzamento de duas variedades altas deve resultar numa variedade ainda mais alta. No entanto, existe uma importante exceção que é a característica para a produtividade, em que as variâncias genéticas aditivas e não aditivas parecem estar em igual grau de importância. Esse objeto vem sendo o principal desafio nas pesquisas de melhoramento genético da cana-de-açúcar (Rossetto, 2011).

Ainda, segundo Rossetto (2011), uma questão adicional bastante relevante em relação ao melhoramento genético da cana é a avaliação de novas variedades quanto à adaptação a diferentes ambientes. Sua relevância deriva da necessidade de se selecionar as melhores variedades para as regiões mais aptas. Sendo a cana-de-açúcar originária de baixas latitudes - regiões tropicais, próximas ao Equador -, seu florescimento ocorre apenas com temperaturas altas e elevada umidade. Em vista disso, os principais programas de melhoramento genético da cana-de-açúcar do Brasil possuem estações experimentais no Nordeste.

\section{A inovação no segmento sucroalcooleiro: perspectiva histórica}

A economia açucareira, pelo menos até o final do século XIX, não havia experimentado inversões de lucros em investimentos que se traduzissem mais efetivamente em melhorias técnicas e de infraestrutura. Concordando com Furtado (1959), Baer (2009) argumenta que a maior parte dos lucros proporcionados pelo ciclo da cana-de-açúcar aos senhores de engenho foram gastos com bens de consumo importados.

Para essa reduzida dinâmica de inversões de lucros em capital, contribuiu o modelo da colonização portuguesa no Brasil, onde, até mesmo após o processo de independência, ainda dominava a produção de produtos exóticos para exportação, realizada na grande propriedade monocultora com trabalho escravo (Prado Júnior, 2004, p. 118) e estrutura de mercado monopsônica, por meio da qual o empresário só poderia vender à metrópole ${ }^{5}$, em geral a um valor abaixo do preço de mercado (Eisenberg, 1974, p. 6). Esses fatores inibiram, durante séculos, a formação de um mercado interno além do de subsistência.

Após a Independência e durante todo o século XIX, a indústria açucareira nacional, em particular a nordestina, foi perdendo espaço para outras novas regiões produtoras estrangeiras, especialmente para as colônias europeias da América

(5) Mesmo após a Independência até o final do século XIX, as tarifas discriminatórias e acordos mantiveram a estrutura do comércio colonial. Apenas após 1880, com a Abolição da Escravatura e com a vinda de imigrantes europeus é que o mercado interno começa a se formar e se concentrar no Centro-Sul. 
Central, posteriormente integradas ao mercado estadunidense, a despeito da expansão mundial dos mercados consumidores. Em 1840, o Brasil atendia cerca de 9\% da demanda mundial por açúcar, e Pernambuco respondia por um terço dessa participação. No início do século seguinte, a participação nacional na demanda não chegava a $2 \%$, e Pernambuco era responsável por um quarto dessa procura. Assim, nesse período, apenas o mercado interno protegido restava à indústria açucareira pernambucana; contudo, haja vista a distância dos grandes mercados consumidores nacionais, a crescente concorrência com produtores das regiões emergentes do centro-sul do País e carecendo de investimentos para a elevação da produtividade, a indústria açucareira de Pernambuco se estagnou (Eisenberg, 1974, p. 31).

Somando-se à estagnação econômica no setor, e sendo esse um dos fatores elencados pelo Manual de Oslo (OCDE, 2004) que inibem os investimentos em inovação tecnológica, estava a exploração de vastas terras não utilizadas do Nordeste por meio do trabalho escravo. Terras em abundância incentivavam a expansão da área cultivada em detrimento da elevação da produtividade das plantações, enquanto o trabalho escravo, por não encontrar demanda equivalente de outros setores na região, representava uma oferta de mão de obra a baixo custo, pelo menos na primeira metade do século XIX, o que incentivava sua exploração extensiva. Os empresários (senhores de engenho) eram relutantes em ensinar/aprender novas técnicas, em parte porque eles mesmos eram ignorantes e, em parte por recearem entregar máquinas de grande valor nas mãos de uma mão de obra hostil ou indiferente como a dos escravos (Eisenberg, 1974, p. 42).

Segundo Eisenberg (1974), "os fatores terra e trabalho a baixo custo e uma rotinização" da produção, ajudam a explicar o atraso tecnológico do setor. Outros fatores que podem explicar o baixo nível de investimentos pelos empresários dos engenhos são, para Eisenberg (1974, p. 43):

Capital costs and market insecurity also affected the rate of innovation. The slow accumulation of retained earnings in the traditional engenho, in comparison with the cost of acquiring modern machinery, prevented the average senhor de engenho from adopting modern technology.

Outros fatores, esses econômicos, contribuíram para a não realização de investimentos no setor: a insegurança do mercado de açúcar, no qual os produtores não possuíam controle de preços (mercado concorrencial), e a ausência de um mercado de crédito para os demandantes de investimentos. Ainda, segundo Eisenberg (1974, p. 48), "The relatively low costs of land and labour, low profit

(6) Segundo o autor, os produtores não se interessavam, ano após ano, em qualquer que fosse a mudança na forma de se produzir. As iniciativas individuais, ao se depararem com essa visão dos empresários locais, eram desencorajadas e confirmavam o rotinismo produtivo. O rotinismo é, segundo o Manual de Oslo (OCDE, 2004), um inibidor de inovações. 
rates, the faltering world sugar market, and high tariffs all militated against capitalintensive innovation."

De modo geral, os investimentos modernizantes em usinas de açúcar no setor aconteceram a partir de 1870, quando o Estado brasileiro, de maneira indireta, através dos bancos ou diretamente ao produtor, começou a subsidiar esses investimentos. Entretanto, apenas o subsídio direto obteve resultados na tentativa de modernização do segmento. A fórmula geral dos investimentos de sucesso nas usinas em Pernambuco era o Estado emprestar diretamente o dinheiro para a construção de usinas modernas e, após vários anos, com o não pagamento da dívida, os usineiros recebiam o perdão da dívida como se fosse um subsídio (Eisenberg, 1974, p. 115116). Esse panorama de paternalismo estatal criou poderosas fábricas de açúcar a custos subsidiados.

O tratamento dado ao desenvolvimento tecnológico da cana-de-açúcar na Região Nordeste foi penoso, para não dizer desastroso, no período de 1930 até 1964. O modelo de poder desenvolvido anteriormente a 1930 era assim caracterizado, segundo Rogers (2008, p. 166):

Os plantadores de Pernambuco viam mudança através das lentes de seu poder herdado, uma perspectiva influenciada pelos legados de dominação e escravidão [...], qualquer mudança das rotinas [...] representava uma ameaça implícita às operações de poder que estavam embutidas nelas de forma naturalizada.

Essa era a visão que determinava a letargia evolutiva do setor. Os plantadores possuíam convicção de que a terra era rica e fértil o suficiente para não necessitar de correções químicas ou enriquecimento orgânico para a plantação (Rogers, 2008).

Com o apoio governamental, portanto, o modelo de produção dos engenhos migrou para as usinas. Não que os engenhos deixassem de existir, mas as usinas recebiam a produção dos engenhos para o processamento. $\mathrm{O}$ processo se estendeu dos anos 1870 até 1930. Nesse novo ambiente de produção, nas usinas, havia poderosas máquinas de produzir açúcar, mas havia escassez de insumos, ou seja, de cana-de-açúcar (Valsechi, 1947 apud Rogers, 2008).

Junto com a renovação técnica da indústria açucareira e o maior requerimento de matéria-prima veio uma preocupação com a saúde das canas, tendo em vista o surto do vírus mosaico que havia se espalhado do sul do País. Segundo Rogers (2008, p. 167), "esta mudança foi caracterizada pela substituição e uma crescente necessidade de selecionar variedades por sua adequação às condições peculiares do solo, do declive e da umidade". Percebe-se também uma crescente profissionalização na ciência agrícola, com a criação de congressos (Congresso Brasileiro de Agronomia a partir de 1936) e institutos (Instituto do Açúcar e do 
Álcool - IAA, em 1933, e o Instituto de Pesquisa Agrícola - IPA, em 1935), além de os plantadores começarem a conceder algum espaço para a pesquisa científica e assessoria técnica na região em parceria com o Estado. Com as melhorias técnicas introduzidas por esses órgãos, a produção de açúcar mais do que dobrou entre 1930 e 1960. Entretanto, o crescimento da produção também se deveu à expansão das áreas exploradas ${ }^{7}$.

Surgem, então, novos competidores na produção de açúcar no cenário nacional advindos do Sudeste, onde havia o maior mercado consumidor interno. Além da vantagem da localização, os produtores do Sudeste contavam com clima e topografia mais favoráveis e utilizaram os atributos da modernidade para produzir com custos inferiores de produção.

Pode-se perceber o porquê da demanda dos produtores locais por alguma ação do governo central frente ao avanço na competição desvantajosa para o Nordeste. Segundo Wanderley (1978) apud Lima (1988, p. 77):

Facing this competition, the Northeastern, mainly the "Pernambucanos", sugar mill owners, revealed a great capacity for resistance and political organization. In their discourse they took up the banner of the defense of the region identifying regional interests with their own class interests. The disorganization of Northeastern sugar production, they alleged, would bring about both economic chaos (with unemployment, misery, etc) and have unpredictable effects on the constituted order and national unity.

Esse panorama influenciou o Estado brasileiro a uma intervenção permanente com a inclusão de cotas para cada estado e cada produtor (Lima, 1988). O IAA configurou-se como essa permanente e organizada intervenção estatal.

Após longo período de intervenção, o movimento perdeu força na década de 1990 com a abertura da economia, reformas do Estado e o entendimento de que o setor deveria tornar-se autossuficiente sob pena de sua descontinuidade ${ }^{8}$. Nesse contexto, deu-se a extinção do IAA e do Planalsucar, o órgão de pesquisa criado para apoiar a agroindústria sucroalcooleira. Mais recentemente, em 2005, quando preocupações com a ampliação das competências nacionais para a inovação tecnológica tornaram-se mais evidentes, o governo federal criou o Cetene (Centro de Tecnologias Estratégicas do Nordeste) na tentativa de desenvolver tecnologias

(7) A produtividade dos campos pernambucanos não passava de "magros" 30 a 40 toneladas de cana por hectare, eclipsados pelas 100 toneladas/hectare na Florida ou o resultado espetacular de 150 toneladas/hectare no Havaí. "Os plantadores de São Paulo aumentavam gradualmente sua produtividade, tendo resultados que cresceram ao longo dos anos 1950, e em 1964, eles chegaram a 65 toneladas de cana por hectare. Com a 3X (variedade de cana), os plantadores pernambucanos viram seus rendimentos aumentar consideravelmente. Embora não alcançando ainda aqueles de São Paulo, eles chegaram mais perto de 50 toneladas por hectare" (Rogers, 2008, p. 176-177).

(8) Ações neoliberais incluíram privatização de estatais e fechamento de organizações governamentais na tentativa de diminuir o tamanho da participação do estado brasileiro na economia. 
consideradas estratégicas para a região, inclusive aquelas ligadas ao segmento canavieiro.

Anos antes, foi constituída uma instituição que tem hoje um papel proeminente nas pesquisas ligadas ao setor. Trata-se da Ridesa (Rede Interuniversitária para o Desenvolvimento do Setor Sucroenergético), criada por meio de convênio firmado entre sete universidades federais (UFPR, UFSCar, UFV, UFRRJ, UFS, Ufal e UFRPE) localizadas nas áreas de atuação das Coordenadorias do ex-Planalsucar, abrangendo o corpo técnico e a infraestrutura das sedes das coordenadorias e estações experimentais. Através de convênio com usinas de açúcar e álcool, a Ridesa iniciou suas atividades em 1991 contando com os pesquisadores e as bases regionais do ex-Planalsucar e com professores das respectivas universidades 9 .

\section{O estudo de caso: a inovação nas usinas pernambucanas}

O estudo de caso aqui desenvolvido incluiu a identificação de profissionais ligados às experiências de interação com universidades e institutos de pesquisa das usinas pernambucanas que responderam o questionário mencionado anteriormente, bem como representantes do setor mencionados por esses profissionais, conforme a técnica de pesquisa conhecida como 'snow ball'. Foram entrevistados quatro representantes do setor empresarial, incluindo o presidente do Sindaçúcar, e três pesquisadores, líderes de grupos de pesquisa que interagem com o segmento ${ }^{10}$, entre os meses de junho e dezembro de 2011, tomando-se um roteiro como guia, de modo a permitir a livre manifestação do entrevistado diante dos problemas da pesquisa apresentados no início da entrevista. Todas as entrevistas foram gravadas, sob consentimento do entrevistado.

(9) Segundo Ridesa (2012), "Em 2011, a Ridesa completou 20 anos e está consolidada nas universidades. Tem como base para o desenvolvimento da pesquisa 31 estações experimentais, localizadas nos estados onde a cultura da cana-de-açúcar apresenta maior expressão. A Rede também desenvolve pesquisa nos campus das sete universidades federais, principalmente nos cursos de pós-graduação. Nestes 20 anos de atuação, as universidades federais deram maior ênfase à manutenção e continuidade da pesquisa relacionada ao Programa de Melhoramento Genético da Cana-de-açúcar (PMGCA), que continuou a utilizar a sigla RB para identificar seus cultivares, tendo liberado 65 cultivares. Mais importante que o número de cultivares liberados é o nível de adoção dos mesmos pelo setor produtivo. Atualmente, os cultivares de sigla RB, anteriormente desenvolvidos pelo Planalsucar, e atualmente pela Ridesa, estão sendo cultivados em mais de 50\% da área cultivada com cana-de-açúcar no país, chegando em algumas regiões a representar até $70 \%$ ".

(10) Entende-se que esse número é representativo tanto do setor empresarial, onde apenas três empresas do Nordeste apontadas pelos líderes de grupos de pesquisa como interativas responderam à pesquisa, quanto dos pesquisadores, já que a Ridesa e o Cetene concentram as interações por parte da academia. Nesse sentido, não se espera que o reduzido número de empresas seja representativo de todo o setor, mas que seja representativo das empresas informadas como interativas na pesquisa central sobre Universidade-Empresa, na qual somente 9 usinas no Brasil foram apontadas como interativas. 
Como observado anteriormente, desenvolvimento tecnológico é fundamental para as empresas que enfrentam qualquer tipo de competição. A partir dessa assertiva, para compreender as especificidades do setor, deve-se perguntar: o que é a inovação tecnológica na indústria sucroalcooleira? Nas diversas entrevistas realizadas, constatou-se que existem três focos de possível atuação para inovação no setor: a área agrícola, a área industrial e a de transporte e mecanização.

Nas diversas entrevistas realizadas com representantes do setor, verificamos que a área industrial, extratora de sacarose da cana, apresenta tecnologia relativamente madura, enquanto a área de transporte e mecanização, que dá suporte à atividade principal, ainda é bastante restrita no que concerne à colheita. Assim, o campo é onde as oportunidades para ganhos em termos de inovação são mais evidentes; desse modo, a área agrícola concentra a maior parte da interação universidade-empresa observada no sucroalcooleiro.

Especificamente, as empresas pernambucanas do setor interagem com instituições como a Ridesa e o Cetene, realizando, de alguma forma, P\&D para o desenvolvimento de novas variedades de cana e multiplicação de mudas melhoradas geneticamente. Por esse motivo, o esforço de pesquisa e desenvolvimento nesse locus é feito de maneira contínua, na busca por variedades de cana mais resistentes às intempéries climáticas, que se adaptem aos diversos tipos de solo e que possuam um maior teor de sacarose e uma fibra que seja capaz de produzir mais energia com a sua queima ${ }^{11}$.

As usinas possuem, em geral, um agrônomo ou técnico para os trabalhos de cunho tecnológico no campo, responsável pela interação com os pesquisadores da Ridesa, fornecendo também insumos, logística e mão de obra para experimentos desenvolvidos no campo. A Ridesa negocia a continuidade do seu trabalho de pesquisa e desenvolvimento com a liberação de pesquisadores e bolsistas por parte da UFRPE, e as usinas participam do programa aportando recursos financeiros que dão suporte ao projeto. Pelo que foi possível apurar dos entrevistados, os valores repassados são pequenos, mas têm sido de fundamental importância para dar suporte ao programa de melhoramento genético desenvolvido pela rede. O Cetene participa desse processo com a multiplicação de plântulas na biofábrica para distribuição gratuita aos pequenos produtores de cana e venda destas, de forma subsidiada, ao grande produtor.

$\mathrm{Na}$ área industrial, pelo que dizem os entrevistados, existe pouca interação entre universidade e empresa. Os aspectos relacionados à inovação de processo são solucionados a partir de consultores externos contratados que focam em geral a resolução de problemas pontuais e aprimoramento do processo de extração de

(11) De acordo com João Dutra, pesquisador da Ridesa. Também compartilham dessa visão o presidente do Sindaçúcar, Renato Cunha, e o engenheiro agrônomo do Grupo Serra Grande, Caubi Figueiredo. 
açúcar, álcool e energia a partir da cana. Esses consultores são, preponderantemente, ex-gerentes industriais das próprias usinas. Aspectos como produtividade industrial (ou rendimento industrial), capacidade de moagem e tempo de operação são variáveis observadas na área industrial e representam o lócus central da transformação dos insumos em produto. No entanto, tendo em vista que o processo de produção industrial do açúcar e do álcool a partir da cana é pouco diferenciado nas usinas nordestinas, conforme Sicsú e Silveira (2012), estas têm dado pouca importância a P\&D na fábrica ${ }^{12}$.

O que se observa na prática é que o processamento industrial não tem requerido esforços contínuos de $\mathrm{P} \& \mathrm{D}$. O que predomina é a atividade de consultoria em processo realizada por ex-gerentes industriais contratados pontualmente pelas usinas. Apesar da inexistência e da pouca visibilidade de P\&D na área industrial, é na fábrica que se encontra uma das atividades mais promissoras, no médio prazo, para as usinas, que é a produção de bioeletricidade. No Nordeste, essa possibilidade é limitada, pois a maioria das unidades industriais são do tipo brownfields ${ }^{13}$, por não contarem com tecnologia de ponta no trato da produção como um todo ${ }^{14}$.

Note-se que um fator favorável à competitividade da produção de açúcar e álcool em Pernambuco, e no Nordeste, é que a mesma é mais facilmente escoada para os portos pernambucanos por contarem com uma distância média até o porto menor do que a distância média a ser vencida pelas usinas do Centro-Sul. Além disso, os produtores locais começaram recentemente a exportar o açúcar refinado a granel, processo chamado BIBO (Bulk-in Bags-out), resultando numa pequena agregação de valor ao produto, por conta do refino, e certa diminuição de custos com o ensacamento do produto, que é feito dentro do navio quando este chega ao porto de destino. Esse processo leva a crer que os produtores têm passado adiante parte importante da agregação de valor ao produto, deixando os procedimentos mais específicos para o importador e, por consequência, perdendo oportunidades de inovar com produtos diferenciados, com ensacamento de diferentes tamanhos e tipos de açúcar para atender a diversos segmentos do mercado externo.

(12) Note-se que, segundo Marcos Moraes (UFPE), o setor demanda soluções tecnológicas para questões mais básicas, de forma que procedimentos mais sofisticados, como a introdução do DNA recombinante (produtos transgênicos), não entram nas opções de inovação demandadas pelos empresários.

(13) Brownfields são fábricas antigas que foram recebendo atualizações ao longo do tempo, mas que não possuem a tecnologia de ponta no trato do processo de produção; ao contrário, apenas introduzem adaptações. Geralmente as indústrias localizadas no Nordeste recebem essa denominação. Os Greenfields são estruturas tecnológicas construídas do zero a partir das necessidades do campo para uma produção enxuta e com tecnologia de ponta para o trato da produção. Existem várias usinas no Centro-Sul que recebem essa denominação.

(14) Essa limitação não impossibilita as usinas de evoluírem em termos de eficiência energética através de atualizações. Para isso, o Banco Nacional de Desenvolvimento Econômico e Social (BNDES) disponibiliza incentivos específicos em termos de financiamentos criados com o propósito de geração de excedentes de energia elétrica. 
Completando a tríade das possibilidades de introdução de inovações no setor está o chamado "Corte, Carregamento e Transporte" (CCT). A perspectiva de mecanização no corte e no carregamento, que se configura concretamente como trajetória viável apenas a partir dos últimos anos, é vista como uma solução para o problema ambiental das queimadas que agridem o meio ambiente e motivam um forte clamor social contra as usinas, prejudicando a imagem das empresas. Adicionalmente ao fator social, está a perspectiva de redução nos custos com CCT, particularmente diante da perspectiva de escassez de mão de obra num futuro próximo.

Por outro lado, estudos recentes sobre a mecanização na colheita da cana crua têm chamado atenção para o maior percentual médio de perdas na colheita mecanizada, de 10 a 15\% da cana-de-açúcar crua colhida (Rosa et al., 2009; Reis, 2009; Mello; Harris, 2003), enquanto a colheita manual registra, em média, perdas de $5 \%$ da cana colhida. Os motivos são diversos, como a altura do corte das colhedoras de cana, o desgaste das facas do corte de base e possíveis danos causados à soqueira. Essas dificuldades são mais evidentes quando se trabalha com terrenos irregulares, como os encontrados em Pernambuco. Desse modo, elevar o percentual da colheita mecanizada pode, em alguns casos, se traduzir em redução da produtividade por hectare. Esse é um desafio que precisa ser enfrentado de modo a tornar a colheita mecanizada mais eficiente. Mesmo assim, diante do clamor social, boa parte dos produtores de estados do Centro-Sul ratificaram as leis estaduais contra queimadas através de protocolos, estabelecendo prazos mais curtos no sentido de mecanizar a colheita ${ }^{15}$.

Diversos eventos econômicos recentes têm modificado o horizonte do mercado de trabalho para os cortadores de cana em Pernambuco, mais especificamente para os filhos desses, que, no médio e longo prazo, contarão com uma oferta de postos de trabalho mais diversificada em decorrência dos investimentos realizados no Porto de Suape, como uma refinaria de petróleo, alguns estaleiros de grande porte, bem como o Pólo Farmoquímico e a instalação de uma montadora de automóveis na cidade de Goiana-PE. Sobre isso, os entrevistados enfatizam que são sinalizações claras para o setor se preocupar com a possível escassez de mão de obra no futuro próximo e trabalhar na busca da mecanização. Vale destacar que algumas usinas da Mata Sul, onde o terreno é mais acidentado,

(15) O protocolo agroambiental foi assinado por 164 usinas do estado de São Paulo em 2007 como forma de antecipar as datas-limite estipuladas pela lei paulista, tendo em vista os problemas ambientais e de saúde provocados pela queima. Pela legislação, áreas mecanizáveis têm até o fim de 2021 para colocar as máquinas no canavial, e áreas não mecanizáveis (declive superior a 12\%) até o fim de 2031. Com o protocolo, as usinas participantes precisam finalizar a mecanização em 2014 e 2017 para áreas mecanizáveis e não mecanizáveis, respectivamente. Além de São Paulo, Minas Gerais e Paraná também desenvolveram protocolos ambientais similares que preveem a antecipação do fim de queima da cana-de-açúcar (Portal do Agronegócio, 2013 apud EcoFinanças, 2013). 
fecharam parcerias com o Sindaçúcar para financiar prospecções em busca de máquinas que melhor se adaptem ao terreno acidentado da Zona da Mata pernambucana, e a expectativa é que deem início, gradualmente, à colheita mecanizada.

Nesse caso, a atitude das empresas é similar à da maioria de outras empresas em outros setores atuantes no País, ou seja, buscam tecnologia no exterior via compra de máquinas e não se voltam para as instituições de pesquisa locais ou nacionais. Desenvolver tecnologia local requereria um aporte de recursos sistemático para o qual não estão preparadas, tendo em vista a consolidada cultura empresarial, avessa a investimentos em progresso técnico, construída ao longo de centenas de anos, como se observou em seção anterior.

\section{Um setor voltado para o mercado externo}

Em se tratando do direcionamento da produção sucroalcooleira pernambucana, observamos que essas usinas têm o foco voltado para o mercado externo de açúcar. $\mathrm{O}$ mercado interno atendido é o mais próximo das usinas, sem sequer ir muito mais distante das fronteiras do estado, porque contam ali com a concorrência do açúcar do Sudeste. Cerca de $90 \%$ da produção de açúcar são voltados para o exterior, segundo os entrevistados. Apesar dos custos da produção nos brownfields nordestinos serem mais elevados, os usineiros têm aproveitado sua vantagem competitiva logística e as cotas americanas para atender ao mercado externo $^{16}$.

Cabe salientar que Oliveira (2009), fazendo uso de dados da PNAD para os anos de 1992 a 2007, encontra que a renda média nas lavouras de cana-de-açúcar das regiões Norte-Nordeste (NO-NE) tem se mantido abaixo de $60 \%$ da renda média do Centro-Sul (C-S), ou seja, bem inferior. Esse diferencial de renda média é parcialmente justificado pelo percentual de área atendida pela colheita mecanizada. A referida proporção de cana colhida de forma mecanizada no Nordeste não chega a um terço da proporção observada no Centro-Sul ${ }^{17}$.

(16) Segundo Sicsú e Silveira (2012), os custos de produção de cana-de-açúcar nordestina representam $88 \%$ da média mundial, e o custo médio das usinas paulistas representa $76 \%$ da média mundial.

(17) Em 2002, o percentual de colheita mecanizada no Nordeste era de apenas 9\%, enquanto no Centro-Sul chegava a 32,5\% (Idea News, 2002 apud Oliveira, 2002). Segundo o Portal do Agronegócio (2013 apud EcoFinanças, 2013), a área de cana-de-açúcar mecanizada no estado de São Paulo atingiu 72,6\% na safra 2012/13. Segundo os dados da Secretaria Estadual de Meio Ambiente (Sema), a utilização de máquinas para evitar a queima na hora da colheita ficou em $85 \%$ nas usinas. O gargalo ainda está nos fornecedores independentes: o percentual fica pouco acima dos 50\%. Segundo o Prof. Djalma Simões, coordenador da Ridesa, o percentual total de cana colhida em Pernambuco de forma mecanizada na safra 2012/13 foi de 15\%, mas a tendência é de crescimento (sendo $5 \%$ proveniente de máquinas tradicionais para solo regular e o restante com máquinas importadas e adaptadas ao solo irregular). 
De acordo com os entrevistados, esse panorama torna a competição do açúcar nordestino no mercado interno inviável, embora ainda competitiva para exportação. Além da distância consideravelmente menor das usinas pernambucanas até os portos de escoamento, em comparação com a média encontrada nas usinas do Centro-Sul, os portos locais não passam por nenhum risco de "apagão logístico", como já enfrentam alguns dos principais portos do Sudeste. Assim, ainda segundo os entrevistados, a logística tem sido a grande forma de minimizar e neutralizar parte dos custos mais altos dos produtores do Nordeste, onde ainda prevalecem atividades agrícolas manuais, sujeitas a eventuais passivos trabalhistas e à pluviosidade às vezes insuficiente, diferentemente dos padrões predominantes no Centro-Sul, onde existe mais estabilidade climática e reduções constantes de gastos agrícolas nos "CCT's".

O cenário comparativo entre as regiões Nordeste e Centro-Sul, acima descrito, diminui as desvantagens de custo do Nordeste, tendo esta região melhores condições de escoamento do produto final ao exterior, quando, em média, as usinas distam apenas cerca de $60 \mathrm{~km}$ para os terminais portuários. Além disso, os portos de Natal, Cabedelo, Recife, Suape e Maceió apresentam, sobremaneira, menos gargalos do que os existentes nos portos do Centro-Sul (Guerra, 2011). Entretanto, nesse contexto, a vantagem comparativa logística da região se transformou em um inibidor de inovações, conforme o Manual de Oslo. A atitude dos empresários locais diante da vantagem em favor do Nordeste é conservadora, fazendo com que a logística favorável sirva como uma "proteção" contra a busca por menores custos de produção e preços. Além disso, os usineiros pernambucanos têm se valido da isenção de impostos sobre produtos exportados e se aproveitado, quando é o caso, de momentos de alta no preço do açúcar no cenário internacional para vender sua produção e obter melhor retorno ao invés de enfrentar a concorrência com as usinas paulistas por maiores fatias do mercado interno. Com isso, contornam, pelo menos temporariamente, a necessidade de reduzir custos para níveis similares aos das usinas do Centro-Sul e negligenciam investimentos em progresso técnico e sua inserção no sistema local de inovação, adiando, assim, o enfrentamento de problemas estruturais que lhes afetarão no médio prazo.

\section{O papel dos pequenos produtores fornecedores}

Não só de grandes produtores e suas usinas é feito o lado da produção em Pernambuco. Segundo o Sindaçúcar, entre $30 \%$ e $40 \%$ da cana moída no estado são provenientes de pequenos fornecedores e produtores de antigos engenhos de cana que não foram absorvidos pelas usinas. A exemplo do que ocorre com as usinas no que diz respeito à inovação, esses pequenos produtores também têm se valido de incentivos dados pelo governo federal a partir do repasse de mudas reproduzidas na biofábrica do Cetene ou de suportes subsidiados pela Ridesa, fazendo com que, de 
uma forma ou de outra, a tecnologia das mudas de cana-de-açúcar adaptadas à região seja mais difundida entre os produtores.

Note-se que, conforme observam alguns entrevistados, além da importância enquanto fornecedores de matéria-prima, os pequenos produtores têm exercido um forte papel político na defesa dos interesses do setor, por se tratar de uma questão de sobrevivência da pequena propriedade agrícola. Muitos desses produtores têm se organizado em cooperativas e sindicatos (Sindicape e Consecana-PE) e buscado apoio político junto a partidos historicamente considerados de esquerda, que se posicionam em defesa do segmento sucroalcooleiro com o argumento de que se trata de um setor tradicionalmente grande empregador de mão de obra e com boa representatividade da pequena propriedade agrícola do estado.

Embora essa afirmação deva ser melhor estudada, o grande número e a organização patronal desses pequenos fornecedores tende a transformá-los em um segmento com capacidade de pressão sobre o governo estadual. No entanto, confirmando-se o argumento, a proteção assim conquistada também funciona como um inibidor de inovações, conforme o Manual de Oslo, pois se trata de uma atitude fechada e de aversão a riscos e incertezas por parte dos empresários. Parece ser mais fácil, ou menos custoso, para esses fornecedores buscar apoio político e proteção para o setor ao invés de provocar o desenvolvimento de atividades inovativas.

Embora exista uma tendência à diversificação das atividades econômicas urbanas na Zona da Mata de Pernambuco decorrente dos grandes projetos industriais já mencionados, o que se tem observado nos últimos anos ainda é a continuidade da atividade secularmente dominante e a reprodução de um modelo historicamente consolidado. Segundo Lima, et al. (2011, p. 22): "No final das contas, o 'mais do mesmo', ou seja, a continuidade é bem mais perceptível que o novo e assim são reproduzidas as relações assimétricas e a baixa capacidade de gerar o 'processo de desenvolvimento de autopropulsão', conforme Furtado (1959), que ainda caracteriza esta economia."

Note-se que, além da assimetria de condições, acima citada, os usineiros parecem se beneficiar com a "proteção" política mobilizada pelos pequenos produtores, tendo em vista que estes engrossam o discurso em defesa de apoio governamental para as melhorias de condições de produção (facilidade de financiamento, melhoria de infraestrutura etc.) demandadas pelos usineiros. Estes têm conseguido vitórias políticas que mantêm, de alguma forma, o setor ainda estável, o que os leva a adiar mais uma vez o aporte de investimentos em P\&D para o progresso técnico no setor. Instituições como o Cetene e a Ridesa têm socializado o investimento em inovação, causando uma espécie de efeito proteção que se propaga por todo o setor, tendo em vista a importância dos pequenos produtores para o fornecimento de matéria-prima para as usinas. Por outro lado, como no século XIX, 
os produtores encaram o investimento governamental em P\&D como um substitutivo aos esforços inovativos que deveriam realizar internamente às suas empresas ${ }^{18}$.

\section{O lento processo de desnacionalização do capital}

Diferentemente de outros setores voltados para o mercado externo, o sucroalcooleiro pernambucano ainda não parece ter avançado no processo de desnacionalização do capital $^{19}$. Os recentes avanços no caminho da profissionalização da gestão e melhor uso da tecnologia disponível observado em algumas empresas pernambucanas têm despertado o interesse de alguns grupos internacionais. No entanto, os entraves a uma maior abertura do capital têm suplantado as poucas iniciativas geradas nessa direção. Nesse contexto, a dinâmica tecnológica não sofre mudanças mais significativas que poderiam advir da chegada de empresas de capital externo, em princípio mais afeitas a investimentos em P\&D e à interação mais forte com as instituições de pesquisa.

A primeira dificuldade elencada diz respeito às tentativas de se produzir em uma topografia bastante acidentada, como é o caso das usinas da Mata Sul. Pelo que afirmam os entrevistados, algumas empresas já arriscaram uma tímida participação nesse mercado; no entanto, não foram bem-sucedidas e terminaram por encerrar suas atividades empresariais, ou se fundiram com outras usinas, ou ainda foram vendidas a empresas mais tradicionais da região.

Uma segunda dificuldade refere-se à administração das usinas. Em Pernambuco, a maior parte das usinas é dirigida por administração familiar e empresários locais. Não existe nenhuma usina pernambucana que possua governança corporativa (condição necessária para o lançamento de uma $I P O^{20}$ ). Meritocracia e balanços auditados são fatores inclusos no processo de governança corporativa que também foram citados por mais de um dos entrevistados como facilitadores na atração de capitais para o segmento. A ausência de meritocracia leva as empresas a enfrentarem dificuldades no processo sucessório. Uma administração familiar não leva em conta o merecimento para assunção do controle da empresa, levando em conta apenas o direito legal de herança e razões familiares para a sucessão. Como se

(18) Note-se que há aqui similitude com o caso do setor agrícola como um todo, onde, entre outros fatores, o longo tempo de desenvolvimento de tecnologias leva o Estado a atuar nessa área através de instituições públicas de pesquisa, a exemplo da Embrapa.

(19) Esse processo de atração de capitais pode se dar por diferentes formas, seja por meio de lançamento de uma IPO, venda de parte das ações da empresa, seja por formação de parcerias para exploração da atividade em uma joint venture, seja por fusões ou aquisições da empresa por outra entrante interessada na potencialidade de lucros do setor.

(20) IPO é a sigla para a expressão em inglês Initial Public Offering, que significa a abertura do capital de uma empresa no mercado acionário. Grosso modo, a empresa avalia quanto vale, divide esse valor em ações e as disponibiliza para venda na bolsa de valores. 
sabe, problemas com uma sucessão malfeita podem levar até ao fechamento da atividade empresarial.

Já a auditoria dos balanços é fator essencial na sinalização para o mercado de que a atividade conta com resultados confiáveis, e isso não ocorre com muita frequência, ajudando a inibir o interesse do capital externo no setor. Outro fator elencado pelos entrevistados como o que mais gera receio nos investidores são os problemas associados ao tamanho e à forma tradicional de exploração da força de trabalho nas usinas locais. Em adição, os empresários alegam que as leis trabalhistas são por demais rígidas, o que desincentivaria a entrada do capital externo em vista de um possível acentuado passivo trabalhista ${ }^{21}$.

É certo, contudo, que existe uma tendência à mudança, conforme citado anteriormente. Alguns grupos empresariais do setor têm se profissionalizado com a implantação de novas tecnologias e metodologias de gestão administrativa prómercado, como investimento em programas de controle global das atividades empresariais, a exemplo do $S A P^{22}$, e adaptação a exigências de multinacionais que são clientes das usinas. O panorama geral, contudo, é de que o nível de profissionalização ainda está muito aquém do desejado pelos investidores externos.

Assim, após a análise de indicadores de desempenho, o setor tem mostrado recuperação da produção e de eficiência à custa do fechamento de unidades ineficientes, com a concentração da produção agrícola em um menor número de unidades $^{23}$, o que leva ao aumento do rendimento industrial e, consequentemente, à diminuição do gap tecnológico entre as empresas (Sicsú; Silveira, 2012).

Tendo em vista a autossuficiência das usinas em relação aos insumos de energia elétrica, existe uma expectativa de que, num futuro não muito distante, empresas do setor de energia elétrica venham a se aproximar das usinas com o intuito de elevar a produção excedente de energia elétrica a partir do bagaço de cana. Nessa perspectiva, compreendem-se aquisições recentes de algumas usinas por multinacionais do setor energético ${ }^{24}$. Em todo caso, a produção de excedentes de energia elétrica ainda é muito pequena no setor e possuidora de um imenso potencial produtivo, podendo vir a ser a porta de atração de grandes investimentos no setor e uma forma de grandes empresas de energia diversificarem a matriz energética do

(21) Referem-se, explicitamente, à Norma Reguladora n. 31, que trata da segurança e da saúde na agricultura, pecuária, silvicultura, exploração florestal e aquicultura com o objetivo de estabelecer preceitos a serem observados no meio ambiente do trabalho rural, ou seja, condições mínimas para o trabalhador do campo.

(22) Trata-se de pacotes conhecidos como Systems, Applications and Products in Data Processing.

(23) Em 2011, havia 22 usinas ativas no estado de Pernambuco; já em 2014, segundo informações coletadas no site do Sindaçúcar, apenas 16 usinas produzirão no estado (Sindaçúcar - PE, 2014).

(24) Algumas dessas multinacionais são do setor de petróleo e seu refino, como a BP (British Petroleum) e a Shell. 
País, especialmente quando entrar em operação o chamado "smart grid"25. Nesse ínterim, os empresários usineiros poderão vir a interagir com o sistema de inovação local para criar um ambiente mais propício e incentivador da inovação, visando a formação de base para a atração de investimentos de maior retorno.

\section{Uma "modernização conservadora"}

Apesar de observarmos que o setor tem começado a se movimentar em busca de soluções tecnológicas para problemas diversos em sua produção, ainda é evidente a crença de que o Estado deve prover incentivos tecnológicos a partir de órgãos como o Cetene e a Ridesa. O setor sucroalcooleiro, ou sucroenergético, é um setor entendido como "estratégico" para a Região Nordeste por produzir um dos principais produtos de exportação e por ser um tradicional gerador de empregos, sendo assim "merecedor" de atenções governamentais. Nesse contexto, o investimento privado em P\&D não parece ser capaz de se autossustentar e ser objeto motivador de um ciclo virtuoso, cabendo ao Estado um papel mais ativo.

O modus operandi observado confirma a hipótese inicial do estudo, cabendo, no entanto, fazer alguns apontamentos para o que tem mudado e o que continua como outrora. Vale, assim, notar que o segmento em estudo não se trata de uma indústria inovativa por razões histórico-culturais que levaram os empresários a recorrer mais intensa e frequentemente a subsídios fiscais e outros benefícios governamentais do que à introdução e melhoria de produtos ou processos estimuladas pela concorrência. Salienta-se, entretanto, que, com as recentes mudanças e investimentos locais, a mão de obra passa a não ser mais tão barata e abundante como anteriormente, mas, mesmo assim, ainda existe uma tendência à continuação do modelo historicamente adotado a partir de uma morosa modernização financiada em parte pelo Estado brasileiro através de suas instituiçõos de pesquisa.

Por fim, o setor em Pernambuco apresenta momento delicado, com produção de açúcar e álcool cadente, tendo em vista a redução de unidades produtivas e a alta volatilidade dos preços do açúcar associada com as flutuações da produção da Índia. Cabe lembrar que os preços do açúcar afetam os preços do etanol, havendo uma elevada correlação positiva entre eles. Adicionalmente, nos últimos três anos o setor sucroalcooleiro nacional tem criticado a atuação do governo federal na política de manutenção artificial dos preços da gasolina para conter a inflação. Essa ação tem inibido, segundo os produtores, investimentos com vistas ao aumento da produção. Chama-se atenção para o fato de que o panorama criado pela política do governo pode ter dois resultados: em setores onde os empresários possuem perfil inovativo:

(25) Integração sistêmica de diferentes formas de produção de energia, com base na introdução de dispositivos eletrônicos e computacionais que liguem geradores - pequenos e médios, além dos grandes - e consumidores de energia. Ver http://energy.gov/oe/technology-development/smart-grid. 
a resposta mais provável é a elevação do investimento em $P \& D$ para a redução de custos e manutenção da competitividade; já em setores onde o perfil dos empresários é conservador, a resposta mais provável não passa pela elevação dos investimentos, e sim pela solução política. Esse parece ser o caso do setor sucroalcooleiro pernambucano e, de algum modo, nacional.

\section{Considerações finais}

A proposta deste artigo foi verificar a hipótese de que a presença de instituições de pesquisa competentes para atender demandas do setor sucroalcooleiro no estado de Pernambuco, que remonta ao final do século XIX, e sua orientação para o mercado externo, não foram fatores suficientes para propiciar estímulos ao desenvolvimento de uma indústria inovativa no estado. Registros sobre a historiografia do setor mostram que traços marcantes de sua trajetória contribuíram para tornar essa indústria pouco inovativa em vista de sua opção recorrente à exploração de mão de obra barata e apoio governamental através de benefícios, subsídios e barreiras que desincentivam a introdução de novos, ou melhoria de, produtos e processos induzidos pela competição mercadológica.

Ao examinar as interações entre as instituições de pesquisa e empresas do setor reportadas nas entrevistas realizadas no estudo de caso, foram encontradas indicações que confirmam a hipótese de que o setor é historicamente protegido por benefícios governamentais e, por consequência, tende a investir de forma bastante limitada no desenvolvimento de novas tecnologias, mesmo sendo voltado para o mercado externo. Além disso, a introdução de inovações decorre da terceirização de P\&D a instituições públicas de pesquisa como forma de se beneficiar de avanços tecnológicos sem incorrer em riscos e custos elevados. O padrão observado historicamente parece não ter se alterado significativamente, mesmo no momento atual de intensificada concorrência diante da crescente globalização dos mercados. Para o futuro, no entanto, esse cenário poderá ser alterado com o aumento da produção com menores custos no Centro-Sul do País.

A divisão do processo de inovação no setor em três segmentos - agricultura, indústria e transporte e mecanização - expressa o elevado grau de complexidade que o caracteriza. Entretanto, o quadro observado no estudo de caso fundamenta a compreensão de que permanece, na atualidade, o baixo dinamismo inovativo do setor no estado. A tecnologia na indústria é relativamente madura, embora haja espaço para melhoria no que diz respeito ao aumento da eficiência no uso de energia nas usinas, e conta com pequenas intervenções para a elevação de produtividade no 
processo e na gestão introduzidas por consultores contratados periodicamente pelas usinas $^{26}$.

No segmento de transporte e mecanização, observou-se que os baixos salários praticados no mercado de trabalho local têm contribuído para retardar a mecanização da colheita, embora o argumento dos representantes da indústria para esse atraso recaia sobre o relevo acidentado. Vale observar, entretanto, que a elevação da demanda por mão de obra decorrente do dinamismo recente associado ao Complexo Industrial Portuário de Suape tem provocado contração da oferta de trabalho, o que vem levantando preocupações entre os representantes do setor, motivando a procura por tecnologias de mecanização da colheita adequadas ao relevo acidentado.

Finalmente, é na agricultura onde se observa o maior esforço inovativo do setor, voltado para melhoramento genético, embora não se tenha observado investimentos expressivos em agricultura de precisão, dada a incipiência dessa tecnologia no segmento. É no campo do melhoramento genético onde a P\&D do setor vem se concentrando historicamente, envolvendo instituições públicas de pesquisa e, consequentemente, a interação universidade-empresa no setor. Entretanto, as empresas conduzem essas interações terceirizando o esforço inovativo para as instituições de pesquisa, não realizando investimentos na construção de competências tecnológicas internas nas empresas. Os representantes das interações nas empresas entrevistados relatam a inexistência de pesquisadores ou estruturas para o desenvolvimento de pesquisas, o que também não foi encontrado em termos coletivos por iniciativa da representação patronal. Esta estimula as pesquisas na RIDESA, sem contudo fomentar o envolvimento mais intensivo dos seus associados numa agenda de pesquisas de maior impacto no processo produtivo e na competitividade do setor que mobilize os agentes econômicos interessados. $\mathrm{O}$ emprego de mudas melhoradas por parte dos fornecedores de menor porte só foi possível por força da ação do estado com a criação do Cetene e da chamada fábrica de mudas. A interação universidade-empresa observada resulta mais, portanto, da iniciativa dos pesquisadores do que da demanda das empresas. Mesmo esforços para agregar valor ao produto exportado são tidos como irrelevantes, na medida em que o açúcar segue para refino no exterior, segundo reportado por um dos entrevistados da associação patronal.

A análise das entrevistas sugere ratificar a importância de parâmetros histórico-culturais que dificultam as transformações no perfil pouco inovativo do setor verificado na literatura e nas tabelas construídas a partir da base de dados da pesquisa mais ampla. Resultado da atuação empresarial num mercado relativamente

(26) Nesse aspecto (CCT), há uma dinâmica muito maior no Centro-Sul conforme observado no site do Centro de Tecnologia Canavieira (CTC). 
protegido e de baixa concorrência, tais fatores perpetuam gestores com atitudes e cultura conservadoras. Essa proteção é permitida atualmente por uma vantagem comparativa logística e por apoio estatal ao financiamento em pesquisa e desenvolvimento, mesmo que seja esse muito reduzido frente aos desafios a serem enfrentados pelo setor. Em outras palavras, os produtores evitam concorrer no mercado interno, dado que operam a custos mais elevados que os do Centro-Sul, voltando-se para a exportação de açúcar por contarem com custos menores relativamente aos de outros produtores no mercado mundial.

Percebe-se tratar de um setor que vem ensaiando mudanças, mas ainda incapaz de se autossustentar, pelo menos no que diz respeito à busca por inovações. Alguns fatores tendem a pressionar o setor a intensificar a introdução de novas tecnologias, conforme visto, ou seja, a possibilidade de uso mais intenso da cogeração de energia, a perspectiva de escassez de mão de obra junto com as cobranças ambientais no estímulo à mecanização do corte $^{27}$, entre outros aspectos. Entretanto, não se observa, no segmento, uma maior inclinação à busca de maior interação com as instituições de pesquisa, sem falar em investimentos mais significativos em departamentos próprios de P\&D. Nesse contexto, instituições públicas de pesquisa, como a Ridesa e o Cetene, destacam-se como fontes de inovações no setor, reforçando a importância do sistema nacional de inovação, mas também indicando a relativa vulnerabilidade, no médio prazo, de um segmento ainda importante para a economia de Pernambuco, cuja sustentabilidade pode vir a ser comprometida caso a fase desfavorável de preços no mercado internacional seja persistente.

\section{Referências bibliográficas}

BRASIL. Portaria n. 520, de 20 de julho de 2010. Aloca a cota preferencial de açúcar destinado aos Estados Unidos em favor de produtores localizados em usinas do Norte e Nordeste. Diário Oficial da União, Brasília, n. 138, p. 66, Seção 1, 21 jul. 2010.

BAER, W. A economia brasileira. 3. ed. São Paulo: Nobel, 2009. p. 33.

ECOFINANÇAS. Mecanização tem avanço lento em canaviais “independentes”. 2013. Disponível em: http://www.ecofinancas.com/noticias/mecanizacao-temavanco-lento-canaviais-independentes. Acesso em: 12 abr. 2014.

EISENBERG, P. Sugar industry in Pernambuco: modernization without change, 1840-1910. Berkeley: University of California Press, 1974.

FERNANDES, A. C., SILVA, A. S.; SOUZA, B. C. Demanda e oferta de tecnologia e conhecimento em região periférica: A interação universidade-empresa no Nordeste

(27) Conforme visto a mecanização do corte ainda enfrenta o desafio de redução das perdas que podem acarretar diminuição da produtividade por hectare. 
Brasileiro. In: SUZIGAN, Wilson; ALBUQUERQUE, Eduardo; CÁRIO, Sílvio (Org.). Interações de universidades e institutos de pesquisas com empresas no Brasil. Belo Horizonte: Autêntica, 2011. v. 1, p. 338-395.

FERNANDES, A. C.; SILVA, A. S.; SOUZA, B. C. Apresentação sucroalcooleiro. In: SEMINÁRIO NACIONAL DA PESQUISA INTERAÇÃO UNIVERSIDADEEMPRESA NO BRASIL, 11, Campinas, Unicamp, SP, 4 nov. 2009.

FREEMAN, C. The 'National System of Innovation' in historical perspective. Cambridge. Journal of Economics, n. 19, p. 5-24, 1995.

FURTADO, C. Formação econômica do Brasil. Rio de Janeiro: Fundo de Cultura, 1959.

GUERRA, M. C. Projeto de consolidação do sucroenergético em Pernambuco. Apresentado no $1^{\circ}$ Fórum UFPETRO. Recife, PE, 26 ago. 2011.

LIMA, J. P. R. The National Alcohol Programme, State and Capitalism in Northeast Brazil. Thesis (Ph.D.)-University College London, London, 1988.

; PINTO, M.; FERREIRA, S. Economia da zona da mata de Pernambuco: Algo de novo? Mais do mesmo? In: CONGRESSO INTERNACIONAL DA APDR, 17; CONGRESSO DE GESTÃO E CONSERVAÇÃO DA NATUREZA, 5, Bragança, Zamora, Inovação e Território. Açores, Portugal: Universidade dos Açores, 29 jun./2 jul. 2011.

LUNDVALL, Bengt-Ake. National Systems of Innovation: towards a theory of innovation and interactive learning. London: Pinter, 1992.

MELLO, R. C., HARRIS, H. Desempenho de cortadores de base para colhedoras de cana-de-açúcar com lâminas serrilhadas e inclinadas. Revista Brasileira de Engenharia Agrícola e Ambiental, v. 7, n. 2, p. 355-358, 2003. Disponível em: http://www.scielo.br/scielo.php?script=sci_arttext\&pid=S1415-43662003000200029.

Acesso em: 24 mar. de 2014.

MOLIN, J. P. Agricultura de precisão: situação atual e perspectivas. Disponível em: http://www.agencia.cnptia.embrapa.br/Repositorio/agricultura-precisao-situacao_ 000fkl0ctoe02wyiv80sq98yqpxloebw.pdf. Acesso em: 22 jun. 2011.

NELSON, R. (Ed.). National Innovation Systems: a comparative analysis. Oxford and New York: Oxford University Press, 1993.

NIR, D. Regional geography considered from the systems' approach. Geoforum, v. 18, n. 2, p. 187-202, 1987.

OCDE. Manual de Oslo: proposta de diretrizes para coleta e interpretação de dados sobre inovação tecnológica. Tradução: FINEP. 2004. 
OLIVEIRA, A. M. S. As inovações tecnológicas e as novas formas de gestão e controle do capital sobre o trabalho. Revista Pegada Eletrônica, Presidente Prudente, v. 3, n. 1, out. 2002. Disponível em:http://www.prudente.unesp.br/ceget/pegada.htm. Acesso em: 24 mar. 2014.

OLIVEIRA, F. C. M.; ROCHA, J. V.; LAMPARELLI, R. A. C.; ZULLO JUNIOR, J. Variabilidade espacial da produtividade e nutrientes absorvidos pela cultura de cana-de-açúcar visando agricultura de precisão. In: SIMPÓSIO INTERNACIONAL DE AGRICULTURA DE PRECISÃO, 2, Viçosa, MG, 12-14 jun. 2002.

OLIVEIRA, Fabíola Cristina Ribeiro de. Ocupação, emprego e remuneração na cana-de-açúcar e em outras atividades agropecuárias no Brasil, de 1992 a 2007. Dissertação (Mestrado em Economia Aplicada)-Escola Superior de Agricultura Luiz de Queiroz, Universidade de São Paulo, Piracicaba, 2009. Disponível em: http://www.teses.usp.br/teses/disponiveis/11/11132/tde-14042009-084343/. Acesso em: 24 mar. 2014.

PRADO JÚNIOR, C. Formação do Brasil Contemporâneo. 23. ed. São Paulo: Brasiliense, 2004. p. 118.

ROSSETTO, Raffaella. Avanço tecnológico. Agência Embrapa de Informação Tecnológica, Embrapa. 2011. Disponível em: http://www.agencia.cnptia. embrapa.br/gestor/cana-de-acucar/arvore/CONTAG01_15_711200516716.html. e http://www.agencia.cnptia.embrapa.br/gestor/cana-de-acucar/arvore/CONTAG01_ 70_711200516719.html. Acesso em: 25 ago. 2011.

RAMÃO, F. P.; SCHNEIDER, I. E.; SHIKIDA, P. F. A Padrão tecnológico no corte de cana-de-açúcar: um estudo de caso no estado do Paraná. Revista de Economia Agrícola, São Paulo, v. 54, n. 1, p. 109-122, jan./jun. 2007.

REIS, G. N. Perdas na colheita mecanizada da cana-de-açúcar crua em função do desgaste das facas do corte de base. 2009. Tese (Doutorado)-Faculdade de Ciências Agrárias e Veterinárias - Unesp, Campus de Jaboticabal, São Paulo. Disponível em: http://www.fcav.unesp.br/download/pgtrabs/cs/d/2314.pdf. Acesso em: 26 mar. 2014.

RIDESA Histórico. 2012. Disponível em: http://www.ridesa.com.br/?pagina =historico. Acesso em: 5 jul. 2012; 26 mar. 2014.

ROGERS, T. D. Geneticistas da gramínea doce em campos decadentes: variedades de cana-de-açúcar, agrônomos e plantadores na abordagem da modernização agrícola (1930-1964). Revista Clio, Recife, v. 26, p. 161-188, 2008.

ROSA, E. J.; JOSÉ, J. V.; CASTRO, A. S.; GAVA, R. Perdas visíveis de cana-deaçúcar em colheita mecanizada. In: ENCONTRO INTERNACIONAL DE PRODUÇÃO CIENTÍFICA CESUMAR (EPCC), 5, Maringá, PR, 27-30 
out. 2009. Disponível em: http://www.cesumar.br/epcc2009/anais/jefferson _vieira jose3.pdf>. Acesso em: 26 mar. 2014.

ROSEMBERG, N. Karl Marx on the economic role of science. The Journal of Political Economy. v. 82, n. 4, p. 713-728, 1974.

SEBRAE. Desafio Sebrae Caderno de conceitos. 2011, Disponível em: http://www.desafio.sebrae.com.br/Site/DownloadManual. Acesso em: 31 mar. 2011.

SICSÚ, A. B.; SILVEIRA, S. K. Indústrias sucroalcooleiras de Pernambuco: mudanças recentes e seus impactos econômicos. In: MATOS, Aécio G. de (Coord.). Modernização conservadora e desenvolvimento na Zona da Mata de Pernambuco. Recife: Editora Universitária da UFPE, 2012.

SINDAÇÚCAR. AL Produtos - Açúcar. 2014. Disponível em: http://www.sindacucar-al.com.br/produtos/acucar/. Acesso em: 26 mar. 2014.

SINDAÇÚCAR. PE Notícias - Estatísticas. 2014. Disponível em: http://www.sindacucar.com.br/noticias_estatisticas.html. Acesso em: 26 mar. 2014.

SUZIGAN, W.; ALBUQUERQUE, E. A interação entre universidades e empresas em perspectiva histórica. 2008. In: SUZIGAN, W.; ALBUQUERQUE, E.; CÁRIO, Sílvio (Org.). Interações de universidades e institutos de pesquisas com empresas no Brasil. Belo Horizonte: Autêntica, 2011. v. 1, p. 17-44. 